\title{
Editor's Introduction to the Distancing Hypothesis Issue
}

\author{
Samuel Heilman
}

Published online: 1 October 2010

(C) Springer Science + Business Media B.V. 2010

We are devoting this special issue of Contemporary Jewry to a debate and commentaries about what has come to be called the "Distancing Hypothesis," the suggestion that American Jews increasingly are socially, culturally, ethnically, and emotionally distant from the State of Israel. This issue of the journal came out of a panel on the subject that was held at a session sponsored by the Association for the Social Scientific Study of Jewry, the parent body of this journal. (A brief account of this panel is part of the comments of Ronald Miller and Arnold Dashefsky in these pages.) So powerful was the debate and deeply felt were the arguments by both sides and from the assembled audience that, as editor and one of those in the room, I invited the lead researchers to present their arguments in these pages and submit them to the review and commentary of a wide array of scholars and thinkers, and finally to our many readers. What you have before you is the result of that effort.

The two lead papers that play out the debate at least appear (some of the commentators take up and question this matter of the appearances versus reality of the debate) to argue in opposite directions. One, by Steven M. Cohen and Ari Kelman, suggests that young American Jews are now less attached to the State of Israel than was the norm in earlier years, and that this growing distance may not be closed in the future. The other article, by Theodore Sasson, Charles Kadushin and Leonard Saxe, argues that while the young are indeed more distant now, there is evidence that there is a life-cycle element to this alienation, and that overall, as Jews age, they have generally tended to become less distant from Israel. Each paper provides its own data which it claims support its arguments.

While our issue was in preparation, this matter became part of the public debate after Peter Beinart raised it in The New York Review of Books (June 10, 2010) when he cited the work of one team of our lead authors (Cohen and Kelman) and reminded readers of the growing distance of young American Jews from Israel.

S. Heilman (ه)

Department of Sociology, CUNY Graduate Center, New York, NY, USA

e-mail: scheilman@gmail.com 
The stir Beinart's article caused in Jewish circles confirmed our commitment to this issue and caused us to move it up in the publication queue.

We have not just printed the main arguments and counter-arguments but have also asked twenty thinkers and scholars to comment on these papers and the arguments, and their remarks are an essential part of the issue. We have also included closing rejoinders by the authors of the two lead papers that react to these comments. While it is difficult and probably not very useful to summarize all the comments, one thing seems clear: many of those who have considered the arguments, including those who have explored this question or related issues on their own, "remain uncertain of where the truth lies," to quote one of the commentators. And all seem to concur that young people today are attached to Israel differently than their elders were.

That is not to say that we are no wiser after all these papers and considerations. On the contrary, this issue more successfully frames and makes explicit the questions, suppositions, and considerations implicit in the debate over the distancing hypothesis. The airing and exploration of the questions associated with this debate here demonstrates far more precisely what researchers will need to do, where they need to look, what they need to discover, the kind of data that is required, as well as what methodologies might be suited to the task in order to arrive at a better answer. At the heart of the methodological difficulties, of course, is the question that many of our commentators touch upon: how and whom do we count as Jews, and can we, as Marvin Schick asks, extrapolate from these numbers?

In our many commentators we also find those who address the essential question of whether this topic is at all important, and if so why or why not. These considerations too must surely be part of the debate.

For the most part, those included in our issue appear to share the lead papers' assumption that a growing distance of American Jewry from Israel would be troubling. That is to say, they share the time-honored belief that American Jewry and Israel should not feel distant from one another and that the Zionist enterprise is not irrelevant to American Jewry. This relationship is important, needs to be accurately monitored, and therefore must be correctly understood and described. Insofar as they do this, they surely must be distinguished from those American Jews for whom this is neither a concern nor a powerfully held value, or even those who believe that distancing is perhaps a good thing - a point raised by Gordon Fellman in these pages. This assumption is worth remembering, for an academic journaleven one such as ours-should always avoid assuming value positions, even as it examines them. For those who consider the answer to the distancing question consequential and interesting (as obviously do the editors and board of the journal), this issue will I hope point the way for a fuller answer. Indeed, Ariella Keysar's call in this issue for a longitudinal national study may therefore be very much in order, although we must consider as well Calvin Goldscheider's warning that: "No simple research design, no matter how elegant, and no body of empirical evidence based on cross-sectional surveys, however complete, is likely to systematically address the nuances of this relationship."

To be sure, the relationship our journal explores is far from straightforward and simple. Israel and American Jewry, as Irving Louis Horowitz among others argues in 
these pages, have related to one another in many complex ways and the relationship has undergone changes since before the founding of the state in 1948. No less, the attachments of Jews to other Jews - as well as to a Jewish State-have experienced a variety of vicissitudes. As those of us who lived longer than others know, shifts in world events, outbreaks of war, political changes in America, Israel and elsewhere, have been able to shake up the relationship in ways that even the most perspicacious social scientists would be incapable of predicting. This is also a point made by Jack Wertheimer, who like several of our commentators sees the need not only to address the findings but also to raise the policy implications of them.

Finally, in order to explore the question, we need to know what activities best measure distance or relation between American Jews and Israel: as Ephraim Tabory asks, for example, "Is talking negatively about Israel with friends a positive indication of engagement with Israel?" Or, as we might add, is not knowing anything or caring nothing about Israel the true measure of distance?

The editors of course do not see our role in offering the definitive answers or making policy recommendations; we are in this case simply agents for presenting the discussion in all its facets. Having explored the distancing question, we do nevertheless believe that in its aftermath we are more ready to get a more definitive answer. We can look for or collect fuller data sets, define our terms and variables more completely, and take into consideration changing historical or social conditions that might affect distancing in the future.

All this being said, no doubt many of the readers of this issue nevertheless will be persuaded by the some of the arguments made here, either because they confirm their own views or else so shake them that they have forced a reconsideration. If that happens, that too will have made the effort worthwhile. Research, like that presented in this journal, can and should provide evidence that will help shape knowledge and opinion, energize ideas, define issues, question assumptions, and ultimately lead to further research. I think we have done that. Some will argue that research is also meant to impact upon policy. If so, then our journal has helped demonstrate that before policies are put into effect, the research must be carefully examined and evaluated.

One last point, many of the responses begin by restating the arguments in the lead papers on which they comment. At first, the editors sought to remove these sections because we felt that readers had read the papers and needed no restatement of them. Yet, as we re-read these commentators' remarks, we began to see that the summaries were also offering glosses that helped unpack their meaning. Commentators described the lead papers somewhat differently, suggesting that they had understood them differently. In a sense this kind of re-presentation is in the best tradition of Jewish commentaries, which often explain by restatement. In the final analysis, these restatements are instructive and we have not edited them out.

I close with thanks for all those who contributed to the discussion and to our managing editor, Yoel Finkelman, for handling the many complications of coordinating such a debate in these pages. I call upon our readers to address and continue to debate the unanswered questions with which we leave you. No doubt, we shall have to return to them in the pages of Contemporary Jewry. I look forward to that. 